\title{
ONLINE MARKETING ISSUES OF REAL ESTATE COMPANIES: A CASE OF LATVIA
}

\author{
Maira DUMPE ${ }^{1}$ \\ ${ }^{I}$ BA School of Business and Finance, Latvia \\ maira.dumpe@ba.lv
}

\begin{abstract}
Today online marketing has become an integral part of marketing mix. Potential real estate customers prefer to make online research themselves. Therefore, real estate companies should be ready that search engines, corporate web pages, profiles on social media sites should strengthen the image of real estate companies and ensure better communication with customers. The aim of this paper is to explore results of qualitative research regarding real estate online marketing activities. It has been found that real estate companies' web sites provide customers with qualitative information. Some companies offer online communication experience. Several companies have created their profiles on Facebook and Twitter but not all of them use social media in an appropriate way. Real estate companies should learn how to use online marketing tools more effectively.
\end{abstract}

Keywords: Corporate web site, information quality, online marketing, real estate, social networks.

\section{INTRODUCTION}

Today, the Internet is one of the most effective communication tools between businesses and customers. Rapidly growing Internet usage has dramatically changed consumers' behaviour. Companies are trying to find new ways how to benefit from the Internet usage, at the same time consumers consider the Internet as a new decision making support tool. The impact of the Internet on business was investigated by many researchers (Constantinides, 2004; Karayanni \& Baltas, 2003). Importance of the Internet in the real estate sector was investigated by Rowley, Razali et al. Rowley viewed the Internet as an effective real estate promotion tool. Razali et al. noted that real estate companies used their web pages for marketing (Rowley, 2006; Razali et al., 2010; Razali et al., 2014).

Real estate companies are interested in selling these properties as soon as possible; therefore, enterprises have effectively used all potential marketing features. According to the previously mentioned research, real estate companies use the Internet as a marketing and customers' information tool (Dermisi, 2004). Using IT, real estate companies can be connected with potential real estate buyers and equip them will all necessary information for buying decision making. Important phase of the purchasing process is searching for information. Nowadays buyers use the web as a research tool. Many researchers stressed importance of quality of information presented on companies' web sites (Gefen, 2000; Aladwani, 2006; Harrison, Waite \& Hunter, 2006). 
The Internet and social networks have changed our lives in unimaginable ways. Different internet resources can help customers in the decision making process. Consumers can get information about real estate from company's web pages, social networks or other Internet resources. There are not many real estate marketing studies performed before in Latvia.

The aim of the present research is explore whether the client can find all the necessary information about real estate on the company's web page and can get online support if additional information is needed and to investigate how real estate companies use social network platforms for communication with potential customers.

\section{REAL ESTATE MARKET}

The real estate market is an important part of every country's economy. Real estate companies analyse real estate prices, demand, country's economic indicators on a regular basis. Buyers and their choice are an essential factor in any industry. It was reported that in the period from 2014 to 2016, in Riga and its near vicinity more than 40 new apartment buildings, private houses and row house projects would be completed, which, according to current estimates, could increase the offer by over 1,000 units (Latio, 2014).

The number of new apartments built during 2014 and 2015 is presented in Table 1.

Table 1. The Number of New Apartments in Latvia (Central Statistical Bureau, 2015)

\begin{tabular}{|c|c|c|c|c|}
\hline Year & 1st Q & 2nd Q & 3rd Q & 4th Q \\
\hline $\mathbf{2 0 1 4}$ & 514 & 404 & 984 & 729 \\
\hline $\mathbf{2 0 1 5}$ & 329 & 720 & 549 & - \\
\hline
\end{tabular}

The statistics regarding new residential buildings is presented in Table 2.

Table 2. New Residential Buildings (thousand sq. m) (Central Statistical Bureau, 2015)

\begin{tabular}{|c|c|c|c|}
\hline Year & Total & Two or more apartments & One apartment \\
\hline $\mathbf{2 0 1 4}$ & 514 & 404 & 984 \\
\hline $\mathbf{2 0 1 5}$ & 329 & 720 & 549 \\
\hline
\end{tabular}

Table 3 presents the number of real estate transactions in Latvia from 2013 to 2015. 
Table 3. The Number of Real Estate Transactions in Latvia (State Land Service of Latvia, 2015)*

\begin{tabular}{|l|c|c|c|c|}
\hline & $\mathbf{2 0 1 3}$ & $\mathbf{2 0 1 4}$ & 2nd Q 2015 & 3rd Q 2015 \\
\hline Apartments & 19796 & 19457 & 4444 & 5104 \\
\hline Buildings & 1642 & 1668 & 431 & 473 \\
\hline
\end{tabular}

Housing market statistical data are presented in Fig. 1.

Appartment transactions in Latvia registered with the Land Register

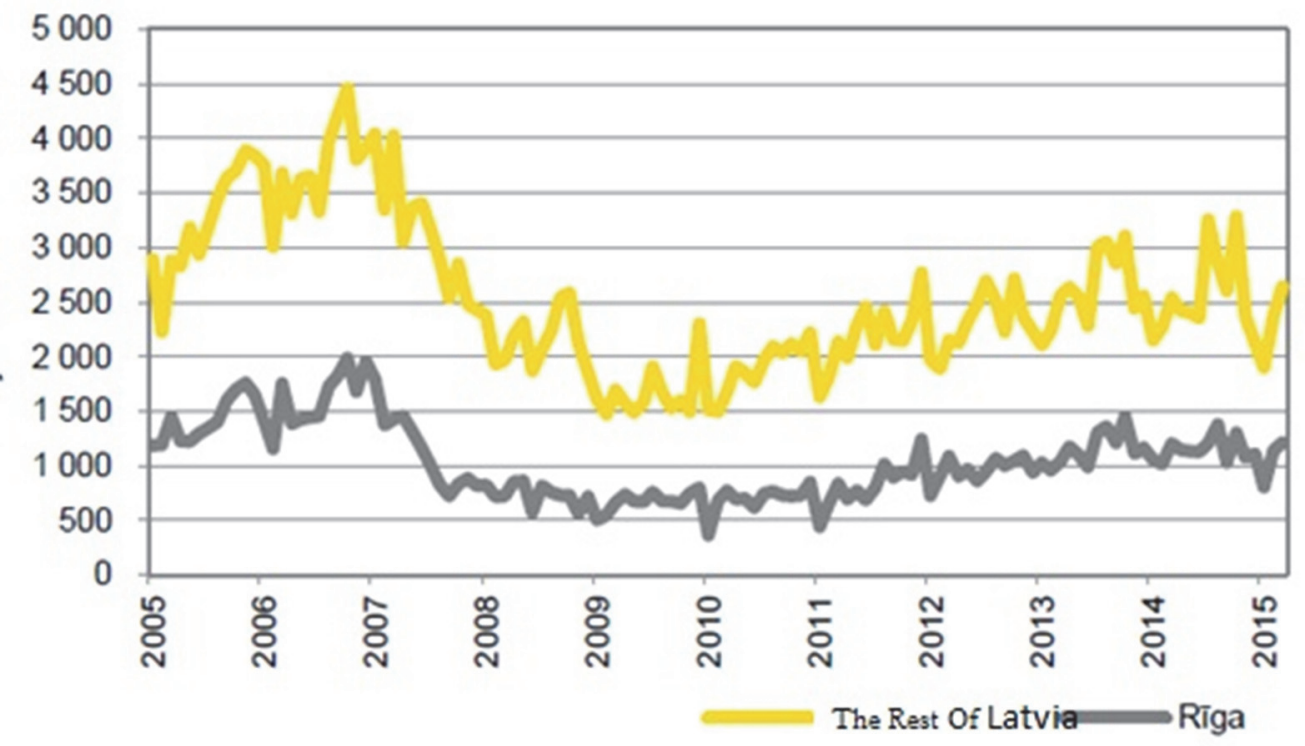

Fig. 1. Number of real estate transactions in the housing sector (Latio, 2013).

According to statistics presented by the Latvian real estate company "Nira fonds", on average 777 apartments are sold per month (Nira, 2014). Thus, taking into account the data presented by the real estate companies data totally, approximately 10000 apartments could be sold last year. At the same time, official statistics shows twice as big number. It could be explained by the fact that real estate companies operate with their own data and consider only deals with newly built apartments.

\section{ONLINE MARKETING}

Today's customers are increasingly using the Internet content, which is presented at different Internet sites. Various Internet media tend to replace traditional media, such as newspapers, TV and radio. According to Bucholtz,

\footnotetext{
* There is no offical statistic data regardig 1st Quater 2015
} 
residents of Latvia give preference to online media rather than traditional, so for any company digital marketing is an important issue (Bucholtz, 2015).

For a countless number of companies, the Internet gives an opportunity to create virtual marketplaces where it is possible to sell their products and provide customers with all the necessary information. At the same time, customers have an opportunity to find all the necessary information, to compare offers provided by various companies and to exchange views regarding the offered products.

Online marketing has many components, but one of the most important components is a corporate web site. The major reason for Internet use by customers is an opportunity to find qualitative information. Companies' web sites should contain complete, proper and sufficient information, otherwise customers will leave the companies' web site. Cox and Dale formulated web site's quality factors. They are "ease of use, customer confidence, on-line resources and customer relation services" (Cox \& Dale, 2002).

Important online marketing tool is SEO (Search Engine Optimization). The purpose of search engine optimization is to rearrange web page content so that a web site appears in the search engine after specific keyword query result list as high as possible.

Social networks are another effective and important online marketing tool, which can help companies to communicate with their customers. The buzz word regarding social media marketing is customer engagement. It means that companies provide their customers with the content that is important to them, which they are ready to comment and share. Typically they spend time attending such social networks as Twitter, Facebook, Draugiem.lv etc. If customers like and share real estate related company posts, they spread companies' marketing message and inform other possible customers about companies' offers.

\section{ONLINE MARKETING FOR REAL ESTATE}

Real estate marketers should consider how to distribute information about real estate to the public. The promotion of real estate is the mix of communication efforts which includes advertising, public relations and sales promotions (Grover, 2012). The sale of real estate is the result of successful marketing campaign. Effective marketing brings a property to the market with the mix of promotion, pricing and distribution.

The Internet has revolutionary changed many industries, including also the real estate industry. Today buyers are gaining more and more access to information than ever before. Potential real estate consumers use the Internet as a research tool where to find the necessary information for supporting buying decisions. Real estate sellers should know that today's customers are very informed.

According to Google research devoted to the analysis of USA real estate buyers' habits (National Association of Realtors, Google 2012), out of $10 \%$ homebuyers use the Internet as one of the primary research tools, and $52 \%$ of customers start their search using the Internet. According to the information presented by Google, the number of real estate searches grows up yearly by $22 \%$. 
The main reason for customers is to find information which can reduce purchasing related risks (Peterson \& Merino, 2003).

In Latvia, $79.7 \%$ of the population now goes online regularly (Latvijas Interneta Asociācija, 2015). Latvian Internet users have the same habits as the Internet users of the USA or developed Western countries. 7 out of 10 Internet users $(70 \%)$ look for information on web pages (CSP, 2015). Real estate buyers read general information about a real estate object and compare prices of various real estate objects.

Zoghlin stated: "All real estate buyers regardless of their age or lifestyle, basically engage in the same four behavioural phases during the process of buying a new home - Discovery, Research, Selection and Closing" (Zoghlin, 2011). During the discovery phase, potential real estate buyers are trying to find as much information as possible. They are investigating all possible offers, compare the real estate objects, their prices and location. This important initial discovery phase has been transformed by the Internet more than any other part of the buying process. During the discovery phase, buyers are visiting web sites of real estate companies. The next phase is research phase when buyers are looking for more specific information and are interested in communication with real estate agents. Some companies provide online contact possibilities, such as online chat or Skype, with the intention to establish closer links with potential customers.

A similar point of view is shared by Kardes. Kardes stated that buyers' "purchasing decision consists of several steps: problem recognition, information search, evaluation of alternative, purchase decision, and post-purchase evaluation" (Kardes, et al, 2011).

For real estate companies, Facebook is a first-rate social network to use as a resource for marketing and communication with clients. Facebook allows companies to create their online profiles and make regularly posts. Facebook users can share, like and comment companies' created posts. Customers can use Facebook to discover new companies or connect with businesses they already know. Facebook and other social networks can be used by customers during the discovery and research phases (Song \& Yoo, 2015). The major benefit for real estate companies from Facebook's usage is the dissemination of information and the expansion of the potential customer base.

Twitter is another social network, which is successfully used for business purposes. For real estate companies, it is recommended to create Twitter accounts. Customers accept Twitter as a marketing tool (Chen, 2015). Twitter can help to distribute the content published on company's website and pin down leads. More and more businesses use Twitter as a powerful marketing tool to quickly and effectively connect with customers and share ideas, updates and events. 


\section{RESEARCH ON ONLINE PRESENCE OF LATVIAN REAL ESTATE COMPANIES}

The main aim of the present research was to investigate how Latvian real estate companies use online marketing tools. Research methodology was similar to the one used by Rowley and Razali (Rowley, 2006, Razali et al., 2010 and 2014 ) - the content analysis of web presence.

Real estate companies' competitors are advertisement portals (ss.lv, reklama. lv, dzivoklis.lv etc.) which offer a lot of announcements from individual persons. After performing a search using keywords "buy apartment", "buy a house", only half of the listings on the first page of Google are from real estate companies, others are from advertising portals. Typical Internet user clicks on the first links on search result lists, so real estate companies should compete with advertising portals.

According to the information presented by the Latvian Real Estate Association (LANĪDA), there are 86 companies - members of real estate association. (Lanīda, 2015). Among them are such companies as Latio, which had 2,927 million turnovers in 2014 (Latio, 2015), and smaller companies which were established for selling specific projects, such as Saliena.

Based on Google query results obtained using different keywords, such as "real estate", "buy apartment", "buy house", 32 Latvian real estate companies were chosen as research sample.

Then the information quality was evaluated, i.e. how easily was to find information, how easy was to understand information and whether information was complete. All these 3 information quality related factors were evaluated on the basis of five-point Likert scale from "strongly disagree" (numeric value -1 ) to "strongly agree" (numeric value -5 ). The information evaluation results are presented in Table 4. Research results indicate that customers can receive qualitative information on real estate companies' web sites.

Table 4. Statistical Results of Information Quality Evaluation

\begin{tabular}{|l|c|c|c|c|c|c|}
\hline & Mean & Median & Mode & St. Deviation & Minimum & Maximum \\
\hline Information quality & 4.32 & 4.5 & 3 & 0.787 & 1 & 5 \\
\hline Easy to understand & 4.03 & 4.00 & 5 & 0.92 & 1 & 5 \\
\hline Information is complete & 4.13 & 4.00 & 5 & 1.070 & 1 & 5 \\
\hline
\end{tabular}

Only 7 out of 32 companies offer online chat or communication via Skype.

The Internet provides companies with a lot of marketing activity analysis tools. Among them are such popular tools as Google Analytics, which presents data for inner use. Companies can compare their activities with competitors' activities by using various online tools. According to Latvian online monitoring service Puls, the number of monthly unique visitors for the most popular advertising portal is more than 10000 (see Table 5). 
Table 5. The Real Estate Web Sites Visitors and Explosion Statistics (Puls.lv, November 2015)

\begin{tabular}{|c|l|c|c|}
\hline \multicolumn{1}{l|}{ No Domain } & Number of visitors & Expositions \\
\hline 1. & Varianti.lv & 11673 & 59152 \\
\hline 2. & Rentinriga.lv & 6926 & 69285 \\
\hline 3. & Dzivoklis.lv & 5006 & 36916 \\
\hline 4. & Westbalt.lv & 2963 & 19313 \\
\hline 5. & Jaunieprojekti.lv & 2663 & 10949 \\
\hline 6. & Nordhaus.lv & 2278 & 14789 \\
\hline 7. & Rigarealestate.lv & 1848 & 10171 \\
\hline 8. & Rg27group.com & 1215 & 9606 \\
\hline 9. & Lateka.lv & 1071 & 8033 \\
\hline 10. & Ava.lv & 1022 & 8093 \\
\hline
\end{tabular}

Next research step was social media presence. 26 companies have their own Facebook profile, but only 13 companies have at least 3 posts during last month. The number of followers is relatively small - Latio has approx. 1400 likes, OberHaus - approx. 280. 18 real estate companies have Twitter accounts and only 11 companies tweet on a regular basis. There are not many Facebook posts or Twitter tweets which call for customers' activities - Likes and retweets. Some companies have created their accounts on a local social network Draugiem.lv and Instagram - mobile and video sharing network.

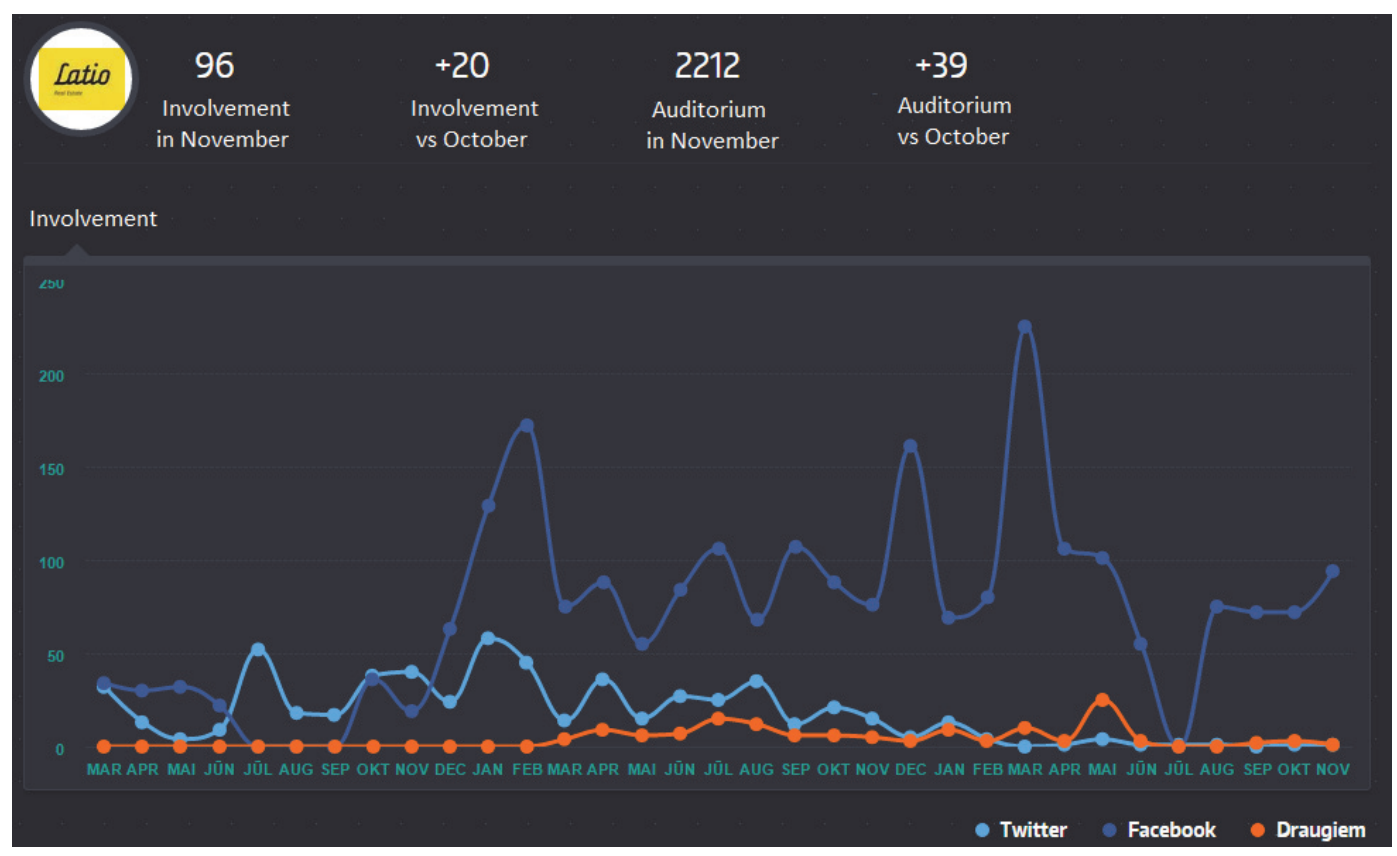

Fig. 2. Social network activities of real estate company Latio (Zīmolu tops). 
For social network marketing activities, monitoring companies can use builtin social network tools or external ones. Brand popularity and influence can be measured by online tool zimolutops.lv, which monitors brand influence and popularity on social network sites. Zimolutops.lv confirms previous observations regarding real estate companies' social network marketing activities - they do not have enough high-quality information. The social network activities of real estate company Latio are presented in Fig. 2.

On the basis of Fig. 2, it can be concluded that Latio does not use social networks for regular communication with customers; similar results are demonstrated by other real estate companies.

The internet has become one of the most important media, so companies need to pay more attention to their digital presence. Competition in the real estate market is quite fierce so that companies should adopt successful digital marketing experience.

\section{CONCLUSION}

Research results indicate that Latvian real estate companies understand the importance of Internet presence. Real estate companies have web sites which present all the necessary information to customers and inform about companies' additional services. Companies present the qualitative information about their selling objects - information is clear, complete and potential customers can easy understand presented information. Some real estate companies are open to establish closer relationships with customers and offer online communication. Unfortunately, there are not many successful Facebook or Twitter usage examples by Latvian real estate companies. Communication in social networks is insufficient. The future research could be related to the analysis of real estate customers' opinion - how potential customers evaluate digital marketing methods and content.

\section{REFERENCES}

Aladwani, A. (2006). An empirical test of the link between web site quality and forward enterprise integration with web consumers. Business Process Management Journal. 12(2), 178-190. http://dx.doi.org/10.1108/14637150610657521

Al-Debei, M. M., Akroush, M. N., Ashouri M. I. (2015). Consumer attitudes towards online shopping. Internet Research, 25(5), 707-733. http://dx.doi.org/10.1108/IntR-05-2014-0146

Baker, B. (2009). Your customer is talking - to everyone: Social media is the new channel for Customer connection. New York: Information management.

Bucholtz, I. (2015). Media Use among Social Networking Site Users in Latvia. International Journal of Communication, 9(2015), 2653-2673.

Chen, H. (2015) College-aged young consumers' interpretation of Twitter and marketing information on Twitter. Young Consumers. 16(2), pp. 208-221. http://dx.doi.org/10.1108/YC-06-2014-00447

Constantinides, E. (2004). Influencing the online consumer's behavior: the Web experience. Internet Research, 14(2), 111-126. http://dx.doi.org/10.1108/10662240410530835

Cox, J., Dale B. G. (2002). Key quality factors in Web site design and use: an examination. International Journal of Quality \& Reliability Management, 19(7), 862-888. http://dx.doi.org/10.1108/02656710210434784 
Central Statistics Bureau. (2015). Computer and Internet usage habits of Latvian population will be found out. Retrieved from http://www.csb.gov.lv/en/notikumi/computer-and-internet-usagehabits-latvian-population-will-be-found-out-41843.html

Central Statistics Bureau. (2015). Property sales (Nekustamā īpašuma pārdošanas darījumi). Retrieved from http://www.csb.gov.lv/statistikas-temas/metodologija/nekustama-ipasumapardosanas-darijumi-38275.html

Dermisi, S. V. (2004). Internet versus traditional office sales. Property Management. 22(2), 155-165. http://dx.doi.org/10.1108/02637470410532411

Duffett, R. G. (2015). Facebook advertising's influence on intention-to-purchase and purchase amongst Millennials. Internet Research, 25(4), 498-526. http://dx.doi.org/10.1108/IntR-01-2014-0020

Gefen, D. (2000). E-commerce: the role of familiarity and trust. OMEGA, 28(6), 725-737. http://dx.doi.org/10.1016/S0305-0483(00)00021-9

Grover, C. (2012). Sales and marketing 101 for the real estate professionals (2nd ed.). Dearbon real estate education. Kaplan Inc. Retrieved from http:/www.dearborn.com/wpcontent/uploads/2015/03/Sales-and-Marketing-101_-2E.pdf

Karayanni, D. A., Baltas, G. A. (2003). Web site characteristics and business performance: some evidence from international business-to-business organizations. Marketing Intelligence \& Planning, 21(2), 105-114. http://dx.doi.org/10.1108/02634500310465416

Kardes, F., Cronley, M. \& Cline, T. (2011). Consumer Behavior. South-Western.

Kyung Young L., Sung-Byung Y. (2015). The role of online product reviews on information adoption of new product development professionals. Internet Research. 25(3), 435-452. http://dx.doi.org/10.1108/IntR-11-2013-0238

Latio, (2014). Housing Market Overview Riga. Retrieved from http:/latio.lv/en/services/marketanalysis-and-review-1/housing-market/124/latio-housing-market-overview-2014-05-en.pdf

Lanīda, (2015). Realty companies. Retrieved from http://www.lanida.lv/index.php?option=com _ content\&view $=$ article\&id $=85 \&$ Itemid $=389 \&$ lang $=$ en

Latvian Internet Association (Latvijas Interneta Asociācija), (2015). Statistics. Retrieved from http://www.lia.lv/statistika.

National Association of Realtors, Google. (2013). The Digital House Hunt: Consumer and Market Trends in Real Estate. Retrieved from http://www.realtor.org/sites/default/files/Study-DigitalHouse-Hunt-2013-01 1.pdf

Nira fonds, (2014). NIRA Fonds: Nekustamo īpašumu tirgū, cenu kategorijā virs 150000 eiro, darījumu skaits ar Latvijas iedzīvotājiem ir niecīgs. Retrieved from http://lanida.lv/index.php? option=com_k2\&view=item\&id=6309:nira-fonds-nekustamo-ipasumu-tirgu-cenu-kategorijavirs-150-000-eiro-darijumu-skaits-ar-latvijas-iedzivotajiem-ir-niecigs\&Itemid=306\&lang=lv.

Peterson, R. A., \& Merino, M. C., (2003). Consumer information search behavior and the Internet. Psychology and Marketing, 20(2), 99-121

Razali M. N., Manaf Z., Yassin, A. M. \&Pahat, B., (2010). Internet business strategies by property companies in Asia. Property Management. 28(4), 270-289. http://dx.doi.org/10.1108/02637471011065692

Razali, M. N., Rahman, R. A., Adnan, Y. M., \& Yassin, A. M. (2014) The impact of information and communication technology on retail property in Malaysia. Property Management, 32(3), 193-212. http://dx.doi.org/10.1108/PM-05-2012-0018

Song, S., \& Yoo, M. (2015). The role of social media during the pre-purchasing stage. Journal of Hospitality and Tourism Technology, 7(1), 28-37

State Land Service (Valsts Zemes Dienests), (2015). Latvian Real Estate Market Statistics (Latvijas Nekustamā īpašuma tirgus - statistiskie rādītāji). Retrieved from http://kadastralavertiba.lv/ tirgus-dati/statistika

Steffes, E., \& Burgee, L. (2009). Social ties and online word of mouth. Internet Research, 19(1), $42-59$.

Zoghlin A. (2011). The Lifecycle of Today's Home Buyer: What Every Brokerage CEO Must Know to Survive. Retrieved from https://www.vht.com/news/PDFS/TheNextGenerationHome BuyerLifecycle.pdf 


\section{AUTHORS' SHORT BIOGRAPHY}

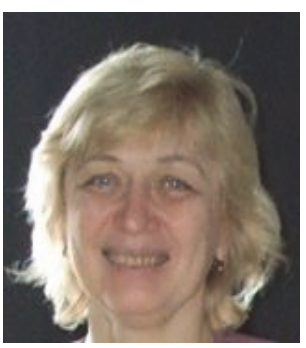

Maira Dumpe received Dipl. Eng. and Professional Master's degree in applied mathematics from Riga Technical University, Faculty of Automation and Computing Technique in 1986. M. Dumpe received the Master of Public Administration degree from the University of Latvia, Faculty of Economics and Management in 1998. Right now Maira Dumpe is working on her Ph. D. Degree at the University of Latvia, Faculty of Pedagogy, Psychology and Arts.

Since 1998 M. Dumpe has been an Assistant Professor of BA School of Business and Finance. Her research interests include information technologies and internet usage for business purposes. From 1993 till 1998 M. Dumpe worked as an International Project Coordinator at Canadian Urban Institute, Riga. From 1986 till 1993 M. Dumpe worked as an Engineer and Lecturer at Riga Technical University, Faculty of Automation and Computing Technique. 